\title{
Hypospadias in Three Generations: Is There a Dominant Responsible Gene for Hypospadias?
}

\author{
Aslan Demir ${ }^{\mathrm{a}, \mathrm{b}}$, Mert Ali Karadag ${ }^{\mathrm{a}}$, Kursat Cecen ${ }^{\mathrm{a}}$, Omer Erkam Arslan ${ }^{\mathrm{a}}$
}

\begin{abstract}
Hypospadias can be defined as a incomplete development of the urethra. Most hypospadias cases show spontaneous occurrence and have no clear cause because the genetic pathways of external genitalia formation are poorly understood. Familial tendency is associated with hypospadias. The brother of an affected boy may also have hypospadias, and this rate is approximately $9-17 \%$. In this case report, we present three hypospadias cases with the same localization that have prolonged to three generations including grandfather, father and three sons. They were applied by their father for circumcision. The socio-economic status of the father was the main reason for the delay of elder brothers' circumcision. We revealed midshaft hypospadias without chordee in three brothers at physical examination. The father also told us he had the same disorder and our physical examination of the father supported hypospadias. Also according to the history taken from father, the grandfather had also hypospadias probably at the same localization. We performed tubularized incised urethral plate to these cases. In the light of these cases, we have thought that there should be a dominant gene responsible for formation of hypospadias.
\end{abstract}

Keywords: Hypospadias; Gene; Molecular genetics

\section{Introduction}

Hypospadias can be defined as a defect in the development of the ventral side of the penis along with and ectopic of the urethral meatus. Hypospadias is the second most common congenital malformation in males, and its incidence is

\footnotetext{
Manuscript accepted for publication January 14, 2014

${ }^{a}$ Department of Urology, Kafkas University Faculty of Medicine, Kars, Turkey

${ }^{\mathrm{b}}$ Corresponding author: Aslan Demir, Kafkas Universitesi Tip

Fakultesi, Uroloji A.B.D, Kars, Turkey.

Email: draslandemir@yahoo.com

doi: http://dx.doi.org/10.14740/jmc1670w
}

$1 / 1,000$ to $1 / 100$ and changes according to the literature due to differences of ethnic origin and countries [1]. There are four main factors contributing to this malformation: environment of child and mother, the endocrine and genetic background of the child, principally gonadal steroid synthesis and the genes of phallic development, the placenta which manages the hormones during the first part of gestation and the mother having possible disorders of hormonal production [2].

In this case report, we wanted to share three hypospadias cases that have prolonged to three generations including father and three sons with the literature.

\section{Case Report}

Three brothers at the ages of 6,17 and 19 years respectively, were applied by their father for circumsicion to our clinic. The socio-economic status of the father was the main reason for the delay of elder brothers' circumcision. The mother was a housewife and she had never worked before. The father was a butcher. The 6-year-old brother had a history of left orchiopexy. We revealed midshaft hypospadias without chordee in three brothers at physical examination. The testes of three brothers were normal in terms of volume and location. The father also told us that he had the same disorder and our physical examination of the father supported hypospadias (Fig. 1). Also according to the history taken from father, the grandfather had also hypospadias probably at the same localization. We performed tubularized incised urethral plate to these cases under general anesthesia.

All of the patients were pre-operatively evaluated with laboratory tests like complete blood count, serum biochemical analysis and testosteron and free testosteron. The results of these tests were normal.

\section{Discussion}

The prevalence of hypospadias varies considerably accross countries, ranging from 4 to 43 cases per 10,000 births [3]. Blacks, Asians and Hispanics are less affected from hypo- 

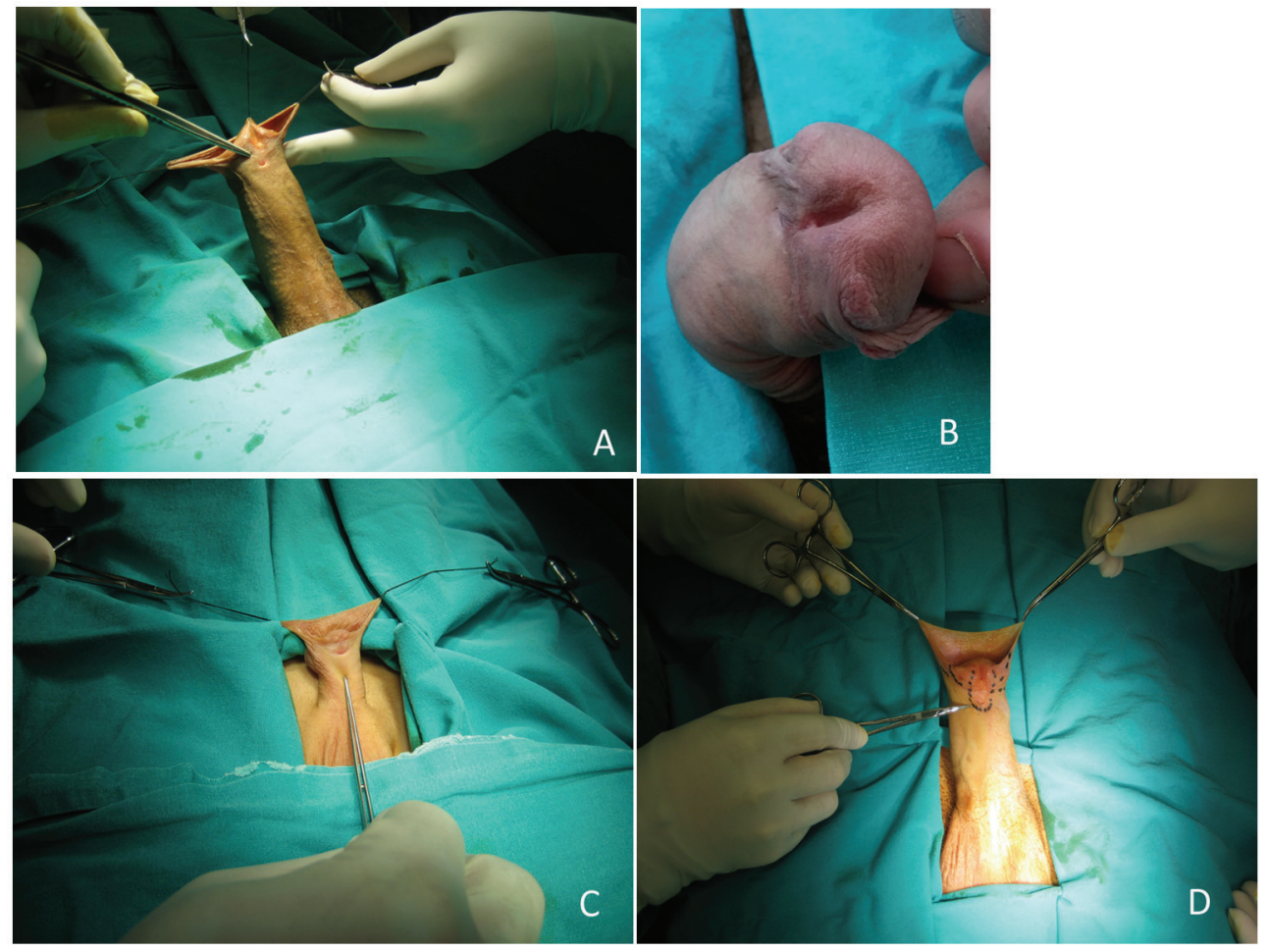

Figure 1. (A) The picture belongs to the middle age brother. (B) The picture belongs to the father. (C) The picture belongs to the youngest brother. (D) The picture belongs to the eldest brother.

spadias than whites [4]. There is a dilemma about if the prevalence of hypospadias is increasing or not. Some authors reported increasing prevalence in China whereas others did not find an increase in the USA $[5,6]$.

Hypospadias is mostly diagnosed during physical examination of the newborn, but localization is establised best during surgery after reconstruction of the chordee. Boys with hypospadias more often have additional congenital anomalies like undescended testes, chordee or more seriously ambigus genitalia, when compared with healthy children [7]. The severity of hypospadias depends on the localization of the meatus. The more proximally localized meatus, the higher degree of congenital anomalies and severity. In our case report, the younger brother underwent left orchiopexy for left undecended testis, and the others had not any additional congenital anomalies.

Most hypospadias cases show spontaneous occurrence and have no clear cause because the genetic pathways of external genitalia formation are poorly understood [8]. Familial tendency is associated with hypospadias, $7 \%$ of cases having first, second or third degree affected relatives [9]. Like our cases, familial occurrence is more common for middle and anterior forms of hypospadias than posterior [9]. The brother of an affected boy may also have hypospadias, and this rate is approximately $9-17 \%$ [10]. This report also showed us that the heritability of hypospadias was estimated to be $57-77 \%$ [10]. This means that $57-77 \%$ of the phenotipic variability may be attributed to genetics. The recurrence risks of sons and brothers of hypospadias cases are similar, and genetics factors rather than environmental factors may play the major role in familial cases [11]. The genetic effect was too clear in our cases due to three generations hypospadias at the same localization. Also, we did not think any effects of chemical exposure to the family members, because of the job of the father and mother.

Several genetic variants carry an increased risk of hypospadias. These genes can be summarized as AR, SRD5A2, HSD17B3, ESR1, ESR2, ATF3, MAMAMLD1/CX or f6 [12]. Immunohistochemical analysis on human preputium tissue revealed that most hypospadiac samples were positive for expression for ATF3 [12]. Also in vitro and some animal studies confirmed this finding [12]. Liu et al reported that fetal exposure to estrogen increased the level of ATF3 messenger RNA [13], whereas this group also indicated that fetal exposure to DEHP (di-2-ethylexyl phthalate) activated transcirption and transduciton of the ATF3 gene [14]. According to our clinical findings, we believed that there should be a dominant gene responsible for hypospadias formation in this family, but due to technical reasons, we could not have a chance to evaluate preputial samples and blood of patients for expression of ATF3 gene and genetic mutations.

Occupational factors have been a major focus in hypospadias research. Especially exposure to pesticides has contradicting results. Giordano et al reported a possible in- 
creased risk for pesiticides in one study [15], besides this three studies focusing on paternal exposure to pesticides before pregnancy did not affect hypospadias [15]. A recent meta-analysis about pesticle exposure indicated only a modestly increased risk of hypospadias [12]. The genetic effect was too clear in our cases due to three generations hypospadias at the same localization. Also, we did not think any effects of chemical exposure to the family members, because of the job of the father and mother.

As a result, hypospadias is a complex congenital anomaly that could be affected by genetic and environmental factors. Herein, we presented three generations cases in a father, possibly grandfather and three sons with hypospadias at the same localization. It was a very different and interesting experience for our clinic to meet such a medical situation. In the light of these cases, we have thought that there should be a dominant gene responsible for formation of hypospadias. To the best of our knowledge, most of the data about hypospadias are depending on case reports, so in our opinion, urology field should focus on genetical studies concerning with familial tendency in hypospadias.

\section{References}

1. Manson JM, Carr MC. Molecular epidemiology of hypospadias: review of genetic and environmental risk factors. Birth Defects Res A Clin Mol Teratol. 2003;67(10):825-836.

2. Wang MH, Baskin LS. Endocrine disruptors, genital development, and hypospadias. J Androl. 2008;29(5):499505 .

3. Nassar N, Bower C, Barker A. Increasing prevalence of hypospadias in Western Australia, 1980-2000. Arch Dis Child. 2007;92(7):580-584.

4. Gallentine ML, Morey AF, Thompson IM, Jr. Hypospadias: a contemporary epidemiologic assessment. Urology. 2001;57(4):788-790.

5. Sun G, Tang D, Liang J, Wu M. Increasing prevalence of hypospadias associated with various perinatal risk factors in chinese newborns. Urology. 2009;73(6):12411245.

6. Fisch H, Lambert SM, Hensle TW, Hyun G. Hypospadias rates in new york state are not increasing. J Urol. 2009;181(5):2291-2294.

7. Latifoglu O, Yavuzer R, Demirciler N, Unal S, Atabay $\mathrm{K}$. Extraurogenital congenital anomalies associated with hypospadias: retrospective review of 700 patients. Ann Plast Surg. 1998;41(5):570-571.

8. Kojima Y, Kohri K, Hayashi Y. Genetic pathway of external genitalia formation and molecular etiology of hypospadias. J Pediatr Urol. 2010;6(4):346-354.

9. Fredell L, Kockum I, Hansson E, Holmner S, Lundquist L, Lackgren G, Pedersen J, et al. Heredity of hypospadias and the significance of low birth weight. J Urol. 2002;167(3):1423-1427.

10. Stoll C, Alembik Y, Roth MP, Dott B. Genetic and environmental factors in hypospadias. J Med Genet. 1990;27(9):559-563.

11. Schnack TH, Zdravkovic S, Myrup C, Westergaard T, Christensen K, Wohlfahrt J, Melbye M. Familial aggregation of hypospadias: a cohort study. Am J Epidemiol. 2008;167(3):251-256.

12. Kalfa N, Philibert P, Baskin LS, Sultan C. Hypospadias: interactions between environment and genetics. Mol Cell Endocrinol. 2011;335(2):89-95.

13. Liu B, Agras K, Willingham E, Vilela ML, Baskin LS. Activating transcription factor 3 is estrogen-responsive in utero and upregulated during sexual differentiation. Horm Res. 2006;65(5):217-222.

14. Liu X, Zhang DY, Li YS, Xiong J, He DW, Lin T, Li XL, et al. Di-(2-ethylhexyl) phthalate upregulates ATF3 expression and suppresses apoptosis in mouse genital tubercle. J Occup Health. 2009;51(1):57-63.

15. van der Zanden LF, van Rooij IA, Feitz WF, Franke B, Knoers NV, Roeleveld N. Aetiology of hypospadias: a systematic review of genes and environment. Hum Reprod Update. 2012;18(3):260-283. 